\title{
BUDI DAYA UDANG WINDU MENGGUNAKAN TANDON MANGROVE DENGAN POLA RESIRKULASI BERBEDA
}

\author{
Gunarto, Suharyanto, Muslimin, dan Abdul Malik Tangko
}

\begin{abstract}
ABSTRAK
Kegagalan panen udang windu masih terus terjadi akibat kerusakan lingkungan perairan pantai. Tujuan penelitian ini adalah untuk mengetahui perbedaan pertumbuhan udang windu dengan pola resirkulasi air yang berbeda dalam budi daya udang ramah mangrove. Penelitian dilaksanakan di Instalasi Tambak Penelitian Maranak, menggunakan tambak ukuran $500 \mathrm{~m}^{2}$. Sebanyak 12 unit terbagi menjadi 9 petak ditebari udang windu dan 3 petak ditebari bandeng untuk biofilter. Tokolan udang windu PL-40 hari dengan bobot rata-rata 0,04 g diskrining terlebih dahulu dengan formalin $200 \mathrm{mg} / \mathrm{L}$ selama 30 menit, selanjutnya ditebar dalam tambak dengan padat tebar 6 ekor $/ \mathrm{m}^{2}$. Variasi pola resirkulasi air dari tandon bakau dialirkan ke petak tandon yang diperkaya dengan Gracillaria sp., terdapat perbedaan aliran air yaitu air masuk langsung ke tambak udang (Perlakuan I), air masuk langsung ke tambak udang yang disisipi bandeng (Perlakuan II), dan air masuk ke biofilter bandeng terlebih dahulu yang selanjutnya air dimasukkan ke tambak udang (Perlakuan III). Masing-masing perlakuan dengan tiga ulangan. Hasil penelitian menunjukkan bahwa dari 9 petak udang, 4 petak terserang WSSV dan mengalami kematian total, sedangkan 5 petak lainnya selamat hingga panen pada hari ke-98 penebaran. Pertumbuhan udang paling baik dijumpai pada perlakuan III mencapai ukuran rata-rata $22,14 \mathrm{~g} \pm 6,86 \mathrm{~g}$ dan perlakuan II rata-rata $10,5 \mathrm{~g} \pm 5,0 \mathrm{~g}$; sedangkan perlakuan I rata-rata $17,66 \mathrm{~g} \pm 4,93 \mathrm{~g}$. Rata-rata pertumbuhan harian $0,18 \mathrm{~g} \pm 0,035 \mathrm{~g}$ (Perlakuan I); $0,11 \mathrm{~g} \pm 0,051 \mathrm{~g}$ (Perlakuan II); dan 0,23 $\mathrm{g} \pm$ $0,048 \mathrm{~g}$ (Perlakuan III). Sintasan dan produksi tertinggi dijumpai pada perlakuan III $(58,05 \% \pm$ $2,29 \%)$ dan $25,6 \pm 8,7 \mathrm{~kg} /$ petak; sedangkan perlakuan II $(44,30 \% \pm 0 \%)$ dan $14,20 \pm 0 \mathrm{~kg} /$ petak; serta perlakuan I $(46,65 \% \pm 13,62 \%)$ dan $19,20 \pm 0,56 \mathrm{~kg} /$ petak.
\end{abstract}

ABSTRACT: Culture of tiger shrimp, Penaeus monodon using mangrove reservoir in the different recirculation systems. By: Gunarto, Suharyanto, Muslimin, and Abdul Malik Tangko

The failure of shrimp harvest from culture still occurs caused by depletion of coastal environment. The objective of the research is to know the growth differences of tiger shrimp, Penaeus monodon cultured using varies recirculation system in mangrove friendly shrimp culture. Research conducted in Maranak Ponds Station using 12 pond compartments each size $500 \mathrm{~m}^{2}$ where 9 compartments were used for shrimp culture and 3 compartments were used for milkfish culture as biofilters. Shrimp juvenile PL-40 days at mean weight $0.04 \mathrm{~g}$ were treated with formaldehide $200 \mathrm{mg} / \mathrm{L}$ at 30 minutes before they stocked in shrimp pond at the density of 6 ind./ $\mathrm{m}^{2}$. The varies of semi-closed recirculation systems of water from mangrove reservoir flowed to pond reservoir enriched with Gracillaria sp., then water flowed to the different ways i.e. directly to the shrimp pond (Treatment I), directly to the shrimp pond inserted with milkfish as biofilters (Treatment II), and water flowed to the milkfish pond biofilters before flowed to the shrimp pond compartment (Treatment III), each treatment in three replicates. The results of the research shown that from 9 shrimp compartments, 4 compatrments were shrimp totally died by WSSV infection, 5 shrimp compartments were saved untill harvested at 98 days of culture. The best growth rate of the shrimp found in the test III with the mean size at $22.14 \mathrm{~g} \pm 6.86 \mathrm{~g}$ and at the test II with mean size $10.5 \mathrm{~g} \pm 5.0 \mathrm{~g}$, while at the test I with mean size $17.66 \mathrm{~g} \pm 4.93 \mathrm{~g}$. The daily growth rates were 0.18 $\mathrm{g} \pm 0.035 \mathrm{~g}$ (test I), $0.11 \mathrm{~g} \pm 0.051 \mathrm{~g}$ (test II), and $0.23 \mathrm{~g} \pm 0.048 \mathrm{~g}$ (test III) respectively. The highest survival rate and shrimp production was found in the test III $(58.05 \% \pm 2.29 \%)$ and $25.6 \pm 8.7 \mathrm{~kg} /$ compartment, while in the test $/ /(44.30 \% \pm 0 \%)$ and $14.20+0 \mathrm{~kg} /$ compartment, also test I $(46.66 \% \pm 13.62 \%)$ and $19.20 \pm 0.56 \mathrm{~kg} / \mathrm{compartment}$.

KEYWORDS: $\quad$ mangrove-friendly, semi-closed resirculation, mangrove reservoir

Peneliti pada Balai Riset Perikanan Budidaya Air Payau, Maros 


\section{PENDAHULUAN}

Berbagai upaya untuk mengatasi kegagalan panen udang windu hasil budi daya tambak akibat serangan penyakit di antaranya menggunakan tandon dan biofilter kekerangan (Atmomarsono et al., 1995; Mangampa et al., 1997) serta biofilter mangrove (Ahmad, 1999; Ahmad \& Mangampa, 1999). Teknologi tersebut masih perlu terus dikembangkan guna mendapatkan hasil yang optimum dalam mengatasi kegagalan panen udang.

Budi daya udang ramah mangrove berarti bahwa di dalam hamparan tambak terdapat hutan mangrove yang difungsikan sebagai biofilter alami air untuk digunakan dalam budi daya udang. Berdasarkan hasil penelitian Halide (1998), kekeruhan menurun sampai sekitar $50 \%$ bila air pasang melewati mangrove selebar 200 m. Selanjutnya Ahmad (2000) melaporkan bahwa mangrove selain dapat menstabilkan konsentrasi $\mathrm{NO}_{3}-\mathrm{N}$ dan $\mathrm{PO}_{4}-\mathrm{P}$ juga mampu menghambat pertumbuhan Vibrio spp. Mangrove juga mampu menjebak dan mendaur ulang berbagai bahan organik, logam berat, dan bahan kimia lain. Organisme yang menempel di akar mangrove juga mampu menyaring dan mendaur ulang berbagai hara (Anonim, 2000; Venhagen, 1998).

Pengkayaan mangrove dengan introduksi bandeng dan tiram akan lebih mengefektifkan fungsi biofilter mangrove. Tiram adalah organisme filter feederyang dapat memanfaatkan kelebihan plankton, bahan organik, jamur, dan flagellata sebagai makanannya (Imai, 1971). Menurut Walne (1972), tiram mampu memfilter air sebanyak $10 \mathrm{~L}$ jam, sedangkan bandeng juga disinyalir mampu bertindak sebagai biofilter (Ahmad, 1999). Air dari petak tandon mangrove sebagai biofilter yang diintroduksi tiram dan bandeng kemudian dialirkan ke petak tandon yang diperkaya dengan Gracillaria sp. Jadi petak tersebut sekaligus sebagai petak pengendapan dan petak biofilter. Kemudian air dialirkan lagi ke petak bandeng sebagai biofilter, sebelum akhirnya air masuk ke petak udang. Maka sistem urutan yang tepat dari pola resirkulasi tersebut diharapkan akan lebih mengefektifkan fungsi biofilter yang pada akhirnya mampu memperbaiki kualitas air untuk budi daya udang sehingga mampu mengurangi kegagalan panen udang.

Tujuan penelitian adalah untuk mengetahui pertumbuhan udang windu dengan pola resirkulasi air semi tertutup yang berbeda dalam budi daya udang windu ramah mangrove.

\section{BAHAN DAN METODE}

Penelitian dilaksanakan di Instalasi Tambak Penelitian Maranak menggunakan satu unit petak mangrove seluas $5.000 \mathrm{~m}^{2}$ yang didominasi oleh Avicennia sp. dan Rhizophora sp. masing-masing dengan kepadatan 11 dan 23 tegakan pohon $/ 25 \mathrm{~m}^{2}$, satu unit petak tandon rumput laut Gracillaria sp. dengan luas $1.500 \mathrm{~m}^{2}, 12$ unit tambak masing-masing ukuran $500 \mathrm{~m}^{2}$ di mana 9 petak ditebari udang dan 3 petak ditebari bandeng sebagai biofilter. Petak mangrove diperkaya dengan tiram sekitar $30 \mathrm{~kg}$ yang dipelihara dalam rak bambu, juga diperkaya dengan gelondongan bandeng yang dipelihara dalam 2 unit keramba ukuran $2 \times 2 \times 1,5 \mathrm{~m}^{3}$ masing-masing dengan padat tebar 500 ekor. Persiapan tambak untuk penebaran sesuai prosedur pembesaran udang windu di tambak dari Mangampa et al. (1999) yang meliputi persiapan tanah dasar tambak, pengeringan, kedok teplok (pengangkatan lumpur dasar tambak), pengolahan tanah dasar, pengapuran, pemberantasan hama, dan pemupukan.

Tokolan udang windu PL-40 dengan bobot ratarata $0,04 \mathrm{~g}$ diskrining dengan formalin $200 \mathrm{mg} / \mathrm{L}$. selama 30 menit terlebih dahulu, baru kemudian ditebar dalam tambak dengan padat tebar 6 ekor $/ \mathrm{m}^{2}$ secara monokultur, sedangkan gelondongan bandeng yang dijadikan sebagai biofilter ditebar di tambak dengan padat tebar 3.000 ekor/ha (Suwardi, 1990).

Pola sirkulasi air, dari tandon bakau yang diperkaya bandeng dan tiram dibagi menjadi 3 perlakuan, yaitu:

Perlakuan I, air dari petak tandon bakau (T. bakau) dialirkan ke tandon yang diperkaya dengan Gracillaria sp. (T. tandon), kemudian dialirkan ke petak pemeliharaan udang (Uu) dan selanjutnya air kembali ke petak tandon bakau.

Perlakuan II, air dari petak tandon bakau dialirkan ke tandon yang diperkaya dengan Gracillaria sp., kemudian air dialirkan ke petak yang ditebari udang dan disisipi bandeng (Ub), kemudian air kembali ke petak tandon bakau.

Perlakuan III, air dari petak tandon bakau dialirkan ke tandon yang diperkaya dengan Gracilaria sp., kemudian air dialirkan ke petak yang ditebari bandeng (B) terlebih dahulu, baru kemudian air dialirkan ke petak yang ditebari udang (U) dan selanjutnya air dialirkan kembali ke petak tandon bakau.

Masing-masing perlakuan dengan tiga ulangan. Untuk lebih jelasnya skema pola sirkulasi air dalam setiap perlakuan dapat dilihat pada Gambar 1.

Tinggi air dalam tambak pemeliharaan dijaga pada kedalaman 70--80 cm. Penggantian air dalam petak udang dilakukan setiap dua minggu sekali sebanyak $10 \%--15 \%$ dengan sumber air berasal dari air saluran yang berasal dari sungai. Model pengelolaan air dilakukan secara resirkulasi semi tertutup. 


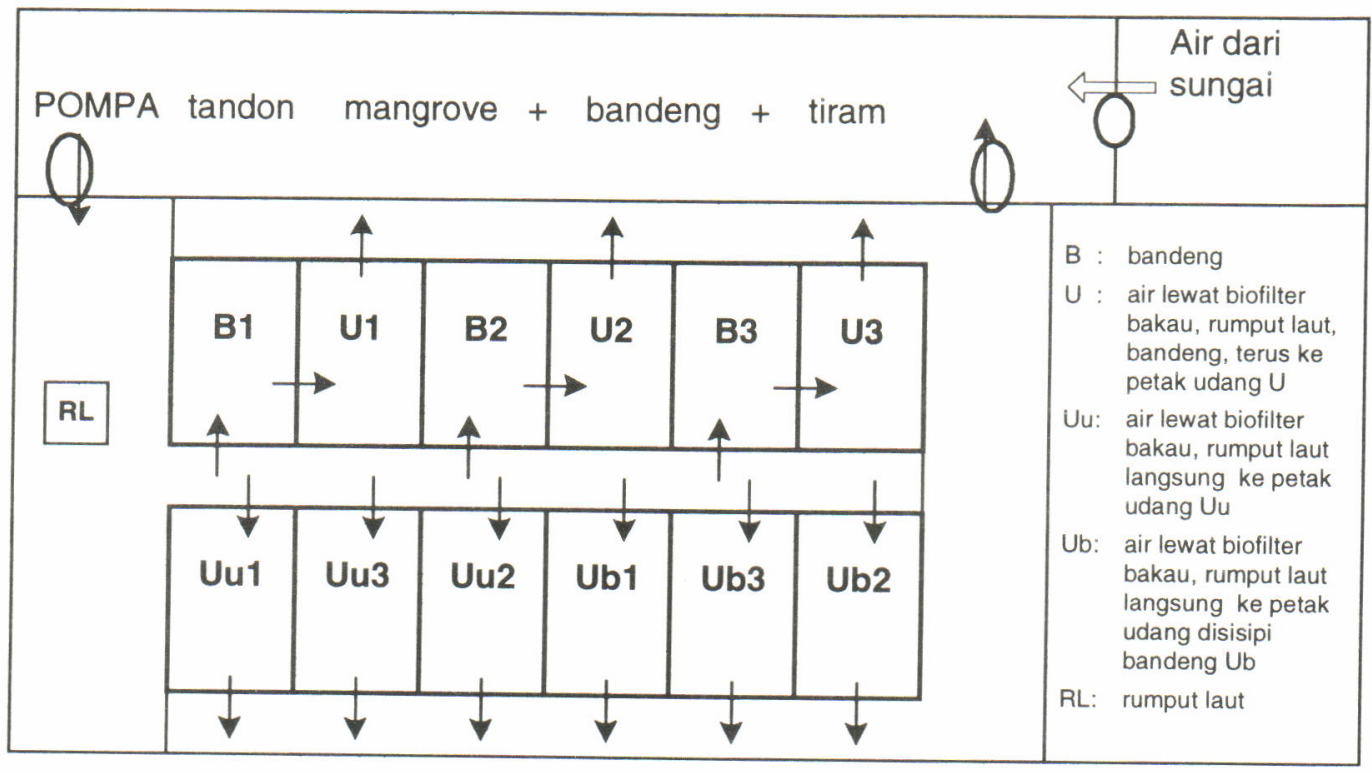

Gambar 1. Pola resirkulasi air dalam budi daya udang ramah mangrove Figure 1. Water recirculation in the mangrove friendly-tiger shrimp culture

Udang diberi pakan buatan (pellet) dimulai dua minggu setelah penebaran sebanyak $10 \%$ dari bobot biomassa/hari dan diberikan dengan frekuensi dua kali pagi dan sore hari selama bulan pertama.

Pada bulan kedua, pakan yang diberikan mulai diturunkan menjadi $6 \%$ dari bobot total biomassa dan pada bulan ketiga diturunkan lagi menjadi 3,5\% dari bobot total biomassa. Penentuan bobot biomassa didasarkan pada bobot udang yang diperoleh pada waktu sampling secara rutin setiap dua minggu sekali (Mangampa et al., 1999). Bandeng dalam petak monokultur tidak diberi pakan tetapi dilakukan pemupukan susulan pada petak tambak setiap dua minggu sekali dengan dosis $9 \mathrm{~kg}$ urea/ha dan $7,5 \mathrm{~kg}$ TSP/ha (Amin et al., 1992).

Sampling pertumbuhan udang diambil dengan cara menangkap secara acak sebanyak 20--30 ekor setiap dua minggu hingga panen. Udang ditimbang dengan timbangan elektrik berketelitian $0,1 \mathrm{~g}$. Sedangkan sampling pertumbuhan bandeng dilakukan hanya pada awal penebaran dan akhir percobaan.

Sampling kualitas air dilakukan sebelum penggantian air setiap dua minggu meliputi salinitas, suhu air, $\mathrm{O}_{2}, \mathrm{NH}_{4}-\mathrm{N}, \mathrm{NO}_{2}-\mathrm{N}, \mathrm{NO}_{3}-\mathrm{N}, \mathrm{PO}_{4}-\mathrm{P}, \mathrm{pH}$, dan Bahan Organik Total (BOT), yang dianalisis berdasarkan prosedur dari Haryadi et al. (1992). Selain itu juga dianalisis kandungan total bakteri di air. Sampling dilakukan pada semua petak tambak, petak bakau, dan petak tandon yang diperkaya dengan Gracillaria sp. Untuk melihat pengaruh perlakuan, karena hanya 5 petak yang selamat yaitu terdiri atas 2 petak perlakuan I, 1 petak perlakuan II, dan 2 petak perlakuan III, data pertumbuhan dianalisis secara deskriptif. Sedangkan untuk melihat korelasi antara pertumbuhan udang dengan kualitas air, maka digunakan perangkat lunak simple correlation dari program SX. Sedangkan untuk melihat pengaruh perlakuan terhadap kualitas air, maka data kualitas air di petak udang dibandingkan dan dianalisis secara deskriptif.

\section{HASIL DAN BAHASAN}

\section{Sintasan dan Pertumbuhan Udang Windu}

Sintasan udang windu hingga hari ke-98 bervariasi. Dari 9 petak yang ditebari udang, 4 petak terserang virus WSSV (White Spot Syndrome Virus) atau bintik putih hingga habis total ketika udang berumur 35--40 hari dari waktu penebaran. Sehingga yang tersisa hanya 5 petak yaitu perlakuan I (dua ulangan), perlakuan II (satu ulangan), dan perlakuan III (dua ulangan). Tanda-tanda udang yang terserang WSSV yaitu udang berenang-renang di pinggir pematang atau menempel di pematang dengan karapas warna buram dan pada sekujur tubuhnya banyak terdapat bintikbintik berwarna putih, lalu dalam 3 hari udang akan mati total. Upaya pencegahannya adalah dengan mengisolasi petak yang sakit, airnya tidak dibuang agar tidak masuk ke petak lainnya, sehingga tidak menularkan penyakitnya ke petak lain.

Pada petak udang yang selamat, dengan padat tebar 3.000 ekor/500 $\mathrm{m}^{2}$ diperoleh sintasan udang masing-masing yaitu perlakuan I $(46,66 \%)$, perlakuan II (44,3\%), dan perlakuan III $(58,12 \%)$ (Tabel 1). Dengan demikian perlakuan III memperlihatkan hasil yang 
terbaik, kemudian disusul oleh perlakuan I dan perlakuan II. Beberapa parameter kualitas air melebihi ambang batas misalnya kandungan total amonia-nitrogen $\left(\mathrm{NH}_{4}-\mathrm{N}\right)$ yang tinggi pada hari ke-28 setelah penebaran yaitu masing-masing mencapai rata-rata 2,95 mg/L (perlakuan II), 1,45 mg/L (perlakuan III), dan $0,649 \mathrm{mg} / \mathrm{L}$ (perlakuan I). Hal ini kemungkinan merupakan faktor awal pemicu mulai mewabahnya serangan virus WSSV, namun untuk membuktikan dugaan tersebut masih perlu dilakukan penelitian secara lebih rinci. Di perlakuan I kandungan $\mathrm{NH}_{4}-\mathrm{N}$ lebih rendah daripada di perlakuan III, hal ini karena tambak udang di perlakuan I mendapatkan air yang berasal langsung dari tandon rumput laut Gracillaria sp. Menurut Neori et al. (1996), rumput laut mampu menyerap amonia yang dikeluarkan oleh udang dan ikan selanjutnya dioksidasi di dalam air. Sedangkan Boyd (1990) menyatakan bahwa konsentrasi amonia sebanyak $0,45 \mathrm{mg} / \mathrm{L}$ dapat menyebabkan pengurangan laju tumbuh pada udang penaeid sebesar $50 \%$. Sedangkan konsentrasi yang aman di tambak adalah di bawah nilai $0,13 \mathrm{mg} / \mathrm{L}$.

Dari tiga perlakuan pola resirkulasi air yang diuji ternyata menghasilkan pola pertumbuhan udang windu yang berbeda. Pertumbuhan harian terbaik dijumpai pada perlakuan III $(0,23 \mathrm{~g} \pm 0,048 \mathrm{~g})$, kemudian disusul oleh perlakuan I $(0,18 \mathrm{~g} \pm 0,035 \mathrm{~g})$, dan $\|(0,11 \pm$ $0,051 \mathrm{~g}$ ) (Tabel 1). Bombeo-Tuburan et al. (1993) menggunakan pakan alami di tambak dengan kepadatan $0,4 \mathrm{ekor} / \mathrm{m}^{2}$ mendapatkan laju tumbuh harian $0,2 \mathrm{~g}--0,36 \mathrm{~g}$. Berdasarkan data kualitas air yang diperoleh ternyata beberapa parameter kualitas air tambak di perlakuan III lebih baik dibanding dengan di perlakuan I dan II. Kandungan BOT paling stabil selama penelitian berlangsung adalah di perlakuan III yaitu pada kisaran 3,50--10,13 mg/L dengan rata-rata $7,15 \mathrm{mg} / \mathrm{L}$. Sedangkan di perlakuan I dan II kandungan BOT berfluktuasi cukup tinggi yaitu mencapai 2,53-$19,36 \mathrm{mg} / \mathrm{L}$ dan 2,53--26,12 mg/L dengan rata-rata masing-masing adalah 10,48 mg/L dan 9,12 mg/L. Ahmad (2000) melaporkan bahwa konsentrasi bahan organik total di air tambak yang ditumbuhi bakau lebih dipengaruhi limpasan debit air daripada dipengaruhi oleh keberadaan bakau. Ini berarti bahwa pada perlakuan III dengan air diresirkulasi melalui tandon bakau, tandon rumput laut, dan tandon bandeng terlebih dahulu sebelum akhirnya masuk ke petak udang, maka keberadaan bandeng sangat bertanggung jawab dalam mengurangi kandungan BOT perairan tambak perlakuan III. Kandungan BOT di perairan berkaitan dengan berkembangnya populasi bakteri, di mana semakin tinggi kandungan BOT maka biasanya populasi bakteri dalam air juga akan semakin tinggi. Pada penelitian ini ternyata populasi bakteri Vibrio sp. baik di perlakuan I, II, dan III semuanya menurun saat sampai di akhir penelitian yaitu pada perlakuan I dari $4,9 \times 10^{2} \mathrm{CFU} / \mathrm{mL}$ (awal) menjadi 1,8 $\times 10^{2} \mathrm{CFU} / \mathrm{mL}$, perlakuan II yaitu dari $3,5 \times 10^{2} \mathrm{CFU} /$ $\mathrm{mL}$ menjadi $2,3 \times 10^{2} \mathrm{CFU} / \mathrm{mL}$, dan perlakuan III yaitu dari $4,4 \times 10^{2} \mathrm{CFU} / \mathrm{mL}$ menjadi $2,2 \times 10^{2} \mathrm{CFU} / \mathrm{mL}$. Menurut Muliani et al. (2000), kandungan bakteri Vibrio harveyi pada kepadatan $10^{3} \mathrm{CFU} / \mathrm{mL}$ sudah menyebabkan patogen pada udang windu.

Tabel 1. Parameter produksi pada pertumbuhan udang windu dengan sistem resirkulasi

Table 1. Production parametrics on the growth of tiger shrimp with the recirculation systems

\begin{tabular}{|c|c|c|c|}
\hline \multirow{2}{*}{$\begin{array}{l}\text { Faktor produksi } \\
\text { Production factors }\end{array}$} & \multicolumn{3}{|c|}{ Perlakuan (Treatments) } \\
\hline & I & II & III \\
\hline $\begin{array}{l}\text { Ukuran petak tambak }\left(\mathrm{m}^{2}\right) \\
\text { Pond size }\left(\mathrm{m}^{2}\right)\end{array}$ & 500 & 500 & 500 \\
\hline $\begin{array}{l}\text { Pond size }\left(\mathrm{m}^{2}\right) \\
\text { Padat tebar }\left(\mathrm{ekor} / \mathrm{m}^{2}\right) \\
\left.\text { Stocking density (ind. } / \mathrm{m}^{2}\right)\end{array}$ & 6 & 6 & 6 \\
\hline $\begin{array}{l}\text { Rata-rata ukuran awal }(\mathrm{g}) \\
\text { Mean size at stocking }(\mathrm{g})\end{array}$ & $0.04 \pm 0.026$ & $0.04 \pm 0.026$ & $0.04 \pm 0.026$ \\
\hline $\begin{array}{l}\text { Rata-rata bobot akhir }(\mathrm{g}) \\
\text { Mean size at harvest }(\mathrm{g})\end{array}$ & $17.66 \pm 4.93$ & $10.50 \pm 5.00$ & $22.14 \pm 6.86$ \\
\hline $\begin{array}{l}\text { Laju tumbuh harian (g/hari) } \\
\text { Daily growth rate ( } g / \text { day) }\end{array}$ & $0.18 \pm 0.035$ & $0.11 \pm 0.051$ & $0.23 \pm 0.048$ \\
\hline $\begin{array}{l}\text { Rata-rata sintasan }(\%) \\
\text { Mean of survival rate }(\%)\end{array}$ & $46.66 \pm 13.62$ & $44.30 \pm 0.00$ & $58.05 \pm 2.29$ \\
\hline $\begin{array}{l}\text { Rata-rata produksi udang }(\mathrm{kg}) \\
\text { Mean of shrimp production }(\mathrm{kg})\end{array}$ & $19.20 \pm 0.56$ & $14.20 \pm 0.00$ & $25.65 \pm 8.69$ \\
\hline $\begin{array}{l}\text { Rata-rata konversi pakan } \\
\text { Mean of feed conversion }\end{array}$ & 2.86 & 3.34 & 2.62 \\
\hline
\end{tabular}


Kandungan nitrit pada perlakuan III juga relatif lebih stabil yaitu pada kisaran $0-0,015 \mathrm{mg} / \mathrm{L}$. Sedangkan pada perlakuan I dan II, kandungan $\mathrm{NO}_{2}-\mathrm{N}$ lebih tinggi dengan puncaknya masing-masing mencapai 0,04 dan $0,06 \mathrm{mg} / \mathrm{L}$. Batas aman konsentrasi nitrit dalam tambak untuk budi daya udang windu adalah di bawah nilai 4,5 mg/L. (Boyd, 1990). Dengan demikian kandungan nitrit di perairan tambak masih jauh dari konsentrasi yang membahayakan bagi kehidupan udang di tambak.

Resirkulasi air pada perlakuan III menghasilkan kualitas air tambak yang lebih baik walaupun tidak secara nyata, tetapi bila dilihat pada nilai pertumbuhan udang, sintasan, produksi, dan konversi pakan yang diperoleh ternyata lebih baik daripada perlakuan I dan II. Nilai konversi pakan pada perlakuan III tersebut masih terlalu tinggi bila dibandingkan dengan hasil penelitian lainnya. Mangampa et al. (1994) mendapatkan koriversi pakan antara 1,29-1,51 pada budi daya udang intensif menggunakan benur yang dibantut terlebih dahulu pada pemeliharaan udang di tambak dengan salinitas pada kisaran 5--20 ppt. Sedangkan pada penelitian ini salinitas telah mencapai 45--50 ppt, walaupun udang tetap ada nafsu makan tetapi pertumbuhan berlangsung lambat, karena sebagian besar energinya banyak digunakan untuk proses osmoregulasi dalam usaha menjaga keseimbangan tekanan cairan tubuh dengan lingkungannya (Poernomo, 1978). Hal ini juga didukung oleh hasil penelitian Suwirya et al. (1986) yang mengatakan bahwa pertumbuhan udang windu pada salinitas 31--32 ppt lebih rendah secara nyata bila dibandingkan pada salinitas 17 -20 ppt dan 12--15 ppt. Selain faktor salinitas yang menyebabkan nilai konversi pakan tinggi juga bisa disebabkan oleh ukuran dari benur yang ditebar. Semakin besar ukuran benur yang ditebar di tambak kemungkinan untuk mendapatkan

Tabel 2. Korelasi antara pertumbuhan udang windu dengan parameter kualitas air di tambak menggunakan pola resirkulasi berbeda

Table 2. The correlation between tiger shrimp growth and water quality parametrics in ponds using different recirculation systems

\begin{tabular}{|c|c|c|c|c|c|c|c|c|c|c|c|}
\hline \multirow[b]{2}{*}{$\begin{array}{l}\text { Variabel } \\
\text { Variables }\end{array}$} & \multicolumn{11}{|c|}{ Variabel (Variables) } \\
\hline & $\begin{array}{l}\text { Bobot } \\
\text { udang } \\
\text { Shrimp } \\
\text { weight }\end{array}$ & $\begin{array}{l}\text { Salinitas } \\
\text { Salinity }\end{array}$ & $\begin{array}{l}\text { Amonium } \\
\text { Amonium }\end{array}$ & $\begin{array}{l}\mathrm{pH} \\
\mathrm{pH}\end{array}$ & $\begin{array}{c}\text { Fosfat } \\
\text { Phosphate }\end{array}$ & $\begin{array}{c}\text { Bakteri } \\
\text { Bacteria }\end{array}$ & $\begin{array}{l}\text { BOT } \\
\text { TOM }\end{array}$ & $\begin{array}{l}\text { OT } \\
\text { DO }\end{array}$ & $\begin{array}{l}\text { Indeks } \\
\text { Index }\end{array}$ & $\begin{array}{l}\text { Nitrat } \\
\text { Nitrate }\end{array}$ & $\begin{array}{l}\text { Nitrit } \\
\text { Nitrite }\end{array}$ \\
\hline $\begin{array}{l}\text { Bobot udang } \\
\text { Shrimp weight }\end{array}$ & 1.000 & & & & & & & & & & \\
\hline $\begin{array}{l}\text { Salinitas } \\
\text { Salinity }\end{array}$ & $0.876^{*}$ & 1.000 & & & & & & & & & \\
\hline $\begin{array}{l}\text { Amonium } \\
\text { Amonium }\end{array}$ & $0.589^{*}$ & 0.394 & 1.000 & & & & & & & & \\
\hline $\begin{array}{l}\mathrm{PH} \\
\mathrm{pH}\end{array}$ & -0.148 & -0.018 & -0.134 & 1.000 & & & & & & & \\
\hline $\begin{array}{l}\text { Fosfat } \\
\text { Phosphate }\end{array}$ & 0.229 & -0.023 & 0.406 . & .0 .215 & 1.000 & & & & & & \\
\hline $\begin{array}{l}\text { Bakteri } \\
\text { Bacteria }\end{array}$ & -0.210 & -0.219 & $-0.054-$ & -0.152 & 0.173 & 1.000 & & & & & \\
\hline $\begin{array}{l}\text { BOT } \\
\text { TOM }\end{array}$ & -0.286 & -0.241 & $0.058-$ & -0.179 & 0.004 & -0.162 & 1.00 & & & & \\
\hline $\begin{array}{l}\text { OT } \\
\text { DO }\end{array}$ & 0.119 & 0.174 & 0.099 & 0.394 & 0.024 & -0.1440 & 0.041 & 1.000 & & & \\
\hline $\begin{array}{l}\text { ID plankton } \\
\text { Plankton ID }\end{array}$ & -0.118 & -0.025 & $=0.302$ & 0.393 & 0.318 & $-0.004 \mathrm{C}$ & 0.011 & 0.051 & 1.000 & & \\
\hline $\begin{array}{l}\text { Nitrat } \\
\text { Nitrate }\end{array}$ & -0.040 & 0.010 & -0.082 & 0.047 & -0.280 & $-0.113 c$ & 0.123 . & -0.013 & -0.014 & 1.000 & \\
\hline $\begin{array}{l}\text { Nitrit } \\
\text { Nitrite }\end{array}$ & 0.113 & 0.220 & -0.177 & 0.034 & -0.292 & 0.0610 & 0.011 & 0.028 & 0.360 & 0.424 & 1.000 \\
\hline
\end{tabular}

*berbeda nyata pada taraf $1 \%$ (significant at level $1 \%$ ) 
nilai konversi pakan yang rendah semakin besar. Pada penelitian ini benur yang ditebar adalah PL-40 dengan ukuran 0,04 g; sedangkan Mangampa et al. (1994) menggunakan benur yang dibantut pada ukuran 0,73$-1,43 \mathrm{~g}$. Di samping itu, semakin tinggi padat tebar udang yang ditebar di tambak maka nilai konversi pakan yang diperoleh kemungkinannya akan semakin tinggi. Selain itu juga bisa disebabkan oleh kesalahan perhitungan populasi pada waktu sampling dilakukan. Sampling populasi udang di tambak umumnya dilakukan pada siang hari, di mana suhu air tambak sudah meningkat sehingga kebanyakan udang akan berkumpul di daerah dasar caren, karena suhu air lebih dingin dari pelataran tambak. Sampling menggunakan jala umumnya dilakukan di sekeliling pematang tambak berarti bahwa udang yang masuk ke jala adalah udang yang berada di caren dan umumnya diperoleh pada kepadatan yang tinggi. Padahal seandainya disampling di pelataran tambak, kemungkinan akan diperoleh udang dalam kepadatan yang rendah. Sehingga apabila sampling dilakukan di kedua areal tersebut, maka akurasi perhitungan populasi udang di tambak akan lebih baik.

\section{Korelasi Pertumbuhan Udang dengan Parameter Kualitas Air}

Korelasi antara pertumbuhan udang dengan parameter kualitas air ditunjukkan dalam Tabel 2, dan ternyata pada salinitas yang semakin meningkat pertumbuhan udang tetap berlangsung $(r=0,8763)$, namun efeknya adalah kandungan amonia dalam air juga semakin meningkat $(r=0,5891)$ dan kedua hal tersebut berkorelasi sangat nyata $(P<0,01)$. Sedangkan parameter kualitas air lainnya seperti kandungan oksigen (DO), bahan organik terlarut (BOT), pH, fosfat, nitrit, nitrat, indeks diversitas plankton, dan kandungan bakteri dalam air tidak memperlihatkan adanya korelasi yang berarti dengan pertumbuhan udang windu dalam tambak.

\section{KESIMPULAN}

Resirkulasi air melalui tandon bakau, tandon Gracillaria sp. dan tandon biofilter bandeng mampu menghasilkan pertumbuhan dan sintasan udang yang lebih baik, serta produksi yang lebih tinggi dibanding perlakuan lainnya.

\section{DAFTAR PUSTAKA}

Ahmad, T. 1999. Pemanfaatan mangrove sebagai biofilter dan bioremediator budidaya udang. Makalah disampaikan dalam Rapat Kerja Teknis dan Pembahasan Hasil-Hasil Penelitian T.A. 1998/1999, Balai Penelitian Perikanan Pantai. Wisma Kinasih Gemilang, Bogor, 16--17 Maret 1999, 16 pp.
Ahmad, T. and M. Mangampa. 1999. The use of mangrove stands for bioremediation in a close shrimp culture system. In Hardjito L. (Ed.). Proceeding of International Symposium on Marine Biotechnology, 29--31 May 2000, Jakarta, p. 114--122.

Ahmad, T. 2000. The use of mangrove stands for shrimp ponds waste-water treatment. JIRCAS International Workshop on Brackishwater Mangrove EcosystemsProductivity and Sustainable Utilization, February 29 March 1st. Tsukuba, Japan, p. 147--153.

Amin, M., Suwardi, dan S. Amini. 1992. Rasio urea dan TSP sebagai pemupukan susulan pada budidaya udang windu, Penaeus monodon di tambak. J. Pen. Budidaya Pantai (8) 4: 85--91.

Anonim. 2000. Florida's Mangroves. "Walking Trees". Department of Environment Protection. Florida Marine Research Institute. St. Petersburg, FL 33.7015.095. 3 pp.

Atmomarsono, M., Muliani, dan S. Ismawati. 1995. Prospek penggunaan tandon pada budidaya udang windu. Makalah disajikan pada Aplikasi Paket Teknologi di Instalasi Penelitian dan Pengkajian Teknologi Pertanian (IPPTP) Wonocolo, Surabaya 2--4 Juli 1995, $10 \mathrm{pp}$.

Boyd, C.E. 1990. Water Quality in Ponds for Aquaculture. Alabama Agricultural Experiment Station, Auburn University. Birmingham Publishing Co. Alabama, 484 pp.

Bombeo-Tuburan, I., N.G. Jr. Guanzon, and G.L.Schroeder. 1993. Production of Penaeus monodon (Fabricus) using four natural food types in an extensive system. Aquaculture, $112: 57--65$.

Haryadi, S., I.N.N. Suryodiputro, dan B. Widigdo. 1992. Limnologi. Penuntun Praktikum dan metode analisis air. Institut Pertanian Bogor. Fakultas Perikanan, 57 pp.

Halide, H. 1998. Pengaruh vegetasi mangrove terhadap kekeruhan dan sedimetasi partikel lumpur. Laporan Penelitian Balai Penelitian Perikanan Pantai, Maros. $4 \mathrm{pp}$.

Imai, T. 1971. Aquaculture in shallow seas: Progress in Shallow Seas Culture. National Technical Information. Service PB 280493 T. p. 151--192.

Mangampa, M., N. Kabangnga, A. Mustafa, dan M. Tjaronge. 1994. Budidaya udang windu Penaeus monodon secara intensif menggunakan benih yang dibantut dalam wadah yang berbeda. J. Pen. Bud. Pantai (10) 5: 89--96.

Mangampa, M., Burhanuddin, M. Tjaronge, dan Muliani. 1997. Pengaruh ukuran cangkang dan kepadatan kerang bakau, Geloina coaxan terhadap perbaikan mutu lingkungan tambak. Laporan Hasil Penelitian, Balai Penelitian Perikanan Pantai Maros, 7 pp.

Mangampa, M., M. Tjaronge, A. Mustafa, dan M. Atmomarsono. 1999. Budidaya udang intensif system biofilter. Kumpulan Paket Teknologi Perikanan Pantai. Balai Penelitian Perikanan Pantai, p. 51--64.

Muliani, A.M. Muharijadi, dan Nurhidayah. 2000. Patogenitas beberapa bakteri Vibrio yang diisolasi dari sedimen tambak terhadap udang windu, 
Penaeus monodon. J. Pen. Perikanan Indonesia (6) 3--4: 44--50.

Neori, A., M.D. Krom, S.P. Ellner, C.E. Boyd, D. Popper, R. Robinovitch, P.J. Davison, O. Dvir, D. Zuber, M. Ucko, D. Angel, dan H. Gordon. 1996. Seaweed biofilters as regulators of water quality in integrated fish-seaweed culture units. Aquaculture 141: 183--199.

Poernomo, A. 1978. Masalah udang penaeid di Indonesia. Simposium Modernisasi Perikanan Rakyat, Jakarta, $27 \mathrm{pp}$.

Suwirya, K., Z.I. Azwar, dan T. Ruchimat. 1986. Pemeliharaan benur windu Penaeus monodon dengan berbagai tingkat kadar garam dalam kondisi laboratorium. J. Pen. Bud. Pantai (2) 1: 34--39.

Suwardi, T. 1990. Pertumbuhan ikan bandeng, Chanoschanos di dalam budidaya terpadu dengan ayam. J. Pen. Budidaya Pantai, 6 (1): 63--69.

Venhagen, H.J. 1998. Mangrove and Fish Ponds. IHFDelft. Diceae. Department of Hydraulic Engineering, $4 \mathrm{pp}$.

Walne, P.R. 1972. The influence of current speed, body size and water temperature on the filtration rate of five species of bivalves. J. Mar. Biol. Ass. U. K., 52: 345--374. 